\title{
BIOLOGI DAN EKOLOGI IKAN PELAGIS KECIL DI PANTAI UTARA JAWA BARAT DAN SELAT SUNDA
}

\author{
Suwarso*) danTuti Hariati")
}

\begin{abstract}
ABSTRAK
Kajian tentang sifat biologi dan ekologi beberapa jenis ikan pelagis kecil pantai dilaksanakan di perairan utara Jawa Barat dan Selat Sunda berdasarkan pada data hasil tangkapan, data biologi selama tahun 2002 , dan survei laut pada dua musim (musim timur dan musim barat). Sampling dilaksanakan terhadap hasil tangkapan tiga tipe mini purse seine. Alat tangkap ini memiliki taktik dan zona penangkapan berbeda di kawasan pantai. Secara umum jenis ikan tembang (Sardinella gibbosa) dan kembung (Rastrelliger brachysoma) selalu dominan di antara 15 spesies neritik yang lain. Perubahan komposisi jenis menurut musim menunjukkan adanya habitat spesifik dari masing-masing jenis ikan yang diduga mengikuti karakter fisik massa air (salinitas). Ikan kembung lebih dominan dalam habitat perairan yang lebih ke pinggir; ikan bentong (Selar crumenophthalmus), banyar (Rastreliger kanagurta), dan layang (Decapterus spp.) tertangkap lebih ke tengah, sedangkan ikan tembang umumnya dijumpai di seluruh kawasan pantai. Berdasarkan pada pola perkembangan gonad (TKG dan nilai $\mathrm{GI}$ ) dan survei larva diduga terdapat indikasi pemijahan pada sekitar musim barat di Kepulauan Seribu (untuk jenis kembung), di Selat Sunda untuk ikan layang, dan di perairan sebelah utara Indramayu untuk ikan kembung. Ikan kembung merupakan ikan pemakan plankton terutama diatom dengan dominasi yang lebih tinggi di perairan utara Indramayu. Perairan utara Indramayu merupakan perairan yang lebih subur dalam hal kandungan plankton (diatom) daripada perairan Teluk Jakarta dan Selat Sunda. Beberapa kondisi fisik perairan pada musim barat dan musim timur juga dibahas.
\end{abstract}

\section{ABSTRACT: Biologi and ecology of small pelagic fishes in the coastal water of northern West Java and Sunda Straits. By: Suwarso and Tuti Hariati}

The investigation on bio-ecological characters of the several coastal small pelagic fishes from north coast of West Java and Sunda Strait was done based on the catch and biological data during year 2002 as well as two sea surveys during east and west monsoons. Samplings were done through the catches of the three kinds of mini purse seines. These fishing gears have different tactics and fishing zone in the coastal area. In general, fringerscale sardine (Sardinella gibbosa) and short-bodied mackerel (Rastrelliger brachyosoma) were always dominant among the other 15 neritic species. The seasonal change of species composition indicated specific habitat (for each species) which probably follow physical character of water mass (e.g. salinity). Short-bodied mackerel tends to live in more inshore, bigeye scad (Selar crumenophthalmus), indian mackerel (Rastrelliger kanagurta), and scads (Decapterus spp.) toward off shore, while fringerscale sardine (Sardinella gibbosa) might be found in the whole of the coastal areas. Based on the pattern of the development of maturity combined with larval distribution, short-bodied mackerel and scads have the spawning ground around Seribu Island waters and both Sunda Strait and northern Indramayu, respectively. Short-bodied mackerel is plankton feeder especially diatoms. Additionally, northern Indramayu is richer waters compared to Jakarta Bay and Sunda Strait. Several physical condition of the waters during the two monsoons are also disscused.

KEYWORDS: biology, ecology, small pelagic fishes, north coast of West Java and Sunda Strait

\section{PENDAHULUAN}

Sumber daya ikan pelagis pantai berperan penting dalam mendukung perikanan tradisional di Laut Jawa. Eksploitasi oleh payang, lampara, dan mini purse seine telah dilakukan sejak lama dan memberi kontribusi sebesar $>50 \%$ dari total produksi ikan pelagis kecil di seluruh Laut Jawa (Hariati et al., 1995). Dengan rata-rata produksi sebesar 79.800 ton per tahun (periode 1990-1994) hasil tangkapan perikanan ini berfluktuasi secara musiman dan tahunan. Jenis-jenis ikan layang (Decapterus spp.) terutama menjadi target penangkapan mini purse seine di pantai utara Jawa bagian timur (Rembang), sedang jenis ikan kembung (Rastrelliger brachysoma) menjadi target penangkapan di pantai utara Jawa bagian barat (Blanakan, Indramayu sampai Jakarta).

Deskripsi secara rinci tentang fasilitas, taktik penangkapan dan aktivitas penangkapan dari berbagai tipe armada mini purse seine (MPS) di sepanjang pantai utara Jawa telah diuraikan oleh Ecoutin \& Dharmadi (1999); kemudian Atmaja (1995), dan Atmaja \& Nugroho (1999) juga telah menjelaskan aspek operasional, aktivitas penangkapan, dan hasil tangkapan mini purse seine terutama yang beroperasi di perairan utara Rembang, Pekalongan, dan Indramayu. Paper ini membahas tentang sifat biologi dan ekologi beberapa jenis ikan pelagis pantai yang tertangkap terutama oleh tiga tipe MPS (Indramayu,

\footnotetext{
") Peneliti pada Balai Riset Perikanan Laut, Jakarta
} 
Brebes, Jawa Timur). Hasilnya diharapkan dapat digunakan sebagai bahan pertimbangan bagi pengelolaan perikanan yang bertanggung jawab dalam kontek melestarikan biodiversitas, di samping sebagai pembanding bagi penelitian lain.

\section{BAHAN DAN METODE}

Daerah penelitian meliputi perairan pantai utara Jawa Barat dan Selat Sunda (Gambar 1). Data yang digunakan meliputi data komposisi jenis hasil tangkapan, biologi (aspek reproduksi, kebiasaan makan), parameter lingkungan fisik (suhu, salinitas, arus, $\mathrm{pH}$, kecerahan), dan biologi perairan (plankton dan larva). Komposisi jenis hasil tangkapan diperoleh dari data harian yang tercatat di Tempat Pelelangan Ikan (TPI) Eretan Wetan (Indramayu) dan hasil tangkapan bulanan yang didaratkan di TPI Blanakan dan Labuhan. Data reproduksi berupa tingkat kematangan gonad selama bulan Mei-Desember 2002, sedangkan data kebiasaan makan ikan berupa komposisi jenis dan jumlah organisme yang terdapat dalam lambung ikan. Survei laut untuk mendapatkan data parameter lingkungan dilaksanakan pada dua musim, yaitu musim barat dan musim timur.

Contoh ikan untuk studi biologi yang diusahakan proporsional menurut kelas panjang diambil secara acak dari hasil tangkapan ketiga tipe mini purse seine yang mendarat di Eretan Wetan, Muara Angke (Jakarta), Rawasaban (Tanggerang), dan Labuhan-
Pasauran (Banten). Ikan contoh terdiri dari ikan-ikan dewasa yang telah dapat dibedakan antara ovari dan testesnya. Untuk ikan layang (Decapterus spp.), banyar ( $R$. kanagurta), dan bentong (Selar crumenophthalmus) pengukuran dimulai pada ukuran $16 \mathrm{~cm} \mathrm{FL}$, sedangkan untuk ikan kembung ( $R$. brachysoma) dan belo (Sardinella brachysoma) mulai ukuran $12 \mathrm{~cm}$ FL. Tingkat kematangan gonad (TKG) ditentukan secara visual mengikuti lima skala maturitas standar sebagai berikut: I (Immature), I| (maturing), III (ripening), IV (ripe), V (spent). Validasi tingkat kematangan ovari dilakukan melalui pengamatan mikroskopis terhadap ukuran dan penampakan telur. Pengamatan isi lambung dilakukan terhadap sampel $1 \mathrm{ml}$ dari total volume $15 \mathrm{ml}$ hasil pengenceran isi lambung.

Pengukuran suhu dilakukan dengan termometer balik (reversing thermometer), salinitas dengan refrakto-salinometer, kecerahan dengan secchi disk, arus dengan topdal arus dan stop watch, dan $\mathrm{pH}$ dengan $\mathrm{pH}$-meter. Contoh fitoplankton diambil dengan jaring plankton no. 25 (diameter $30 \mathrm{~cm}$, mata jaring $70 \mu$ ) yang ditarik secara horisontal sepanjang $20 \mathrm{~m}$; sedang contoh telur/larva diambil dengan jaring larva (bongo net) (diameter $1 \mathrm{~m}$, mata jaring $500 \mu$ ) yang dilengkapi dengan flow meter. Bongo net ditarik selama 10 menit dengan kecepatan kapal 1 knot. Identifikasi jenis plankton berdasarkan Yamaji (1996).

Indeks gonad (GI) digunakan untuk menyatakan tingkat kematangan dan dihitung dengan rumus:

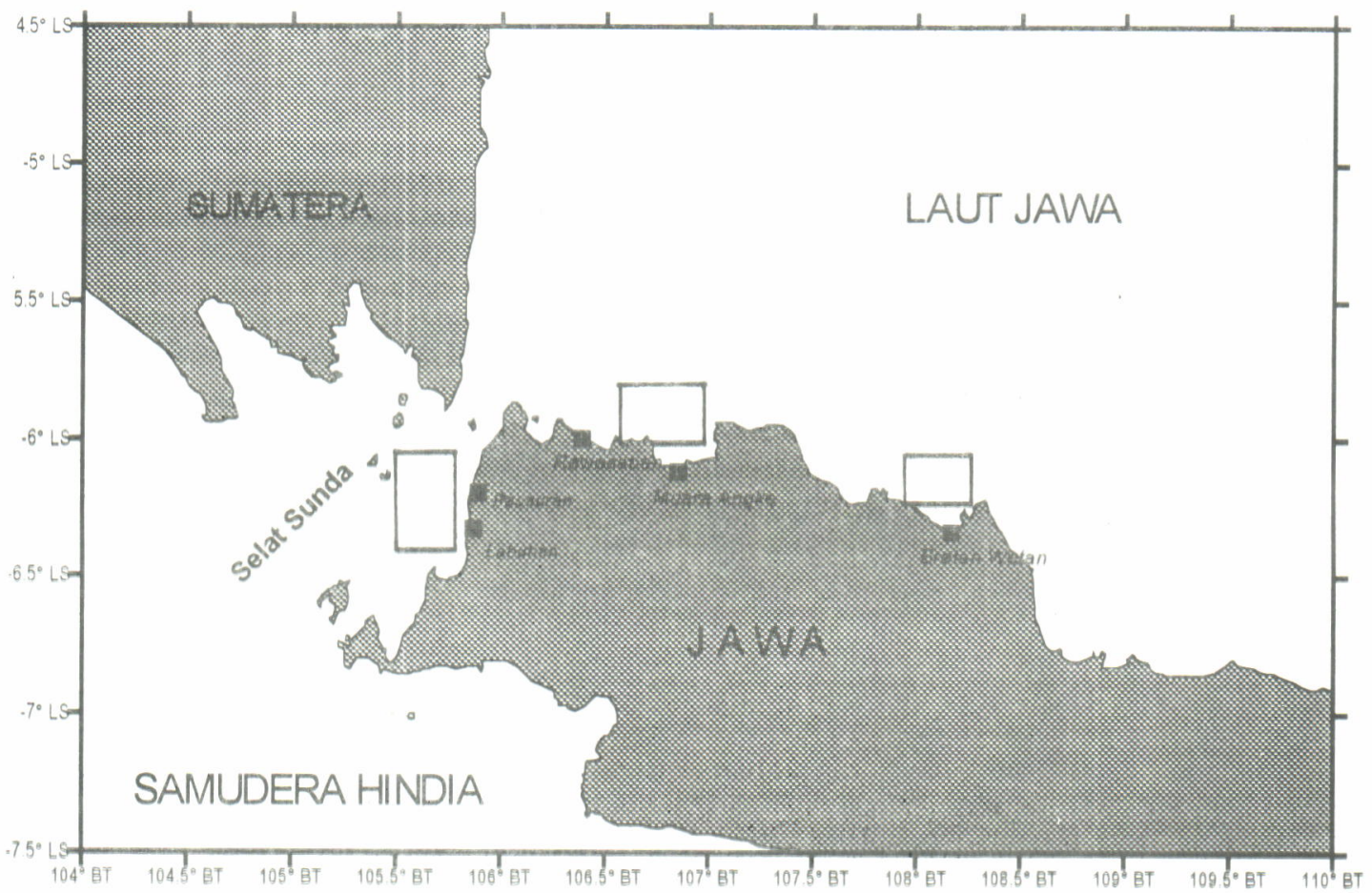

Gambar 1. Peta lokasi penelitian dan lokasi sampling (gambar kotak menunjukkan lokasi sampling larva dan lingkungan).

Figure 1. The sampling sites map (rectangular sign showing the sampling sites for larvae and environmental observation). 
$\mathrm{GI}=\mathrm{W}_{\mathrm{g}} / \mathrm{L}^{3} \times 1000\left(\mathrm{~W}_{\mathrm{g}}\right.$ : berat gonad segar; L: panjang ikan). Kepadatan plankton dihitung dalam jumlah individu per liter air menurut hasil pengamatan terhadap contoh subsampel sebanyak $1 \mathrm{ml}$, sedangkan penghitungan total individu dilakukan terhadap larva/telur yang terjaring.

\section{HASIL DAN BAHASAN}

\section{Perubahan Komposisi Jenis}

Komposisi jenis ikan pelagis pantai yang tertangkap oleh mini purse seine di perairan utara Indramayu berbeda untuk ketiga tipe armada dan bervariasi menurut musim, namun secara umum jenis ikan tembang ( $S$. gibbosa) selalu dominan (44\%). Jenis lain yang dominan adalah kembung $(R$. brachysoma) dan bentong (S. crumenophthalmus), masing-masing 6,4\%. Perubahan komposisi jenis dari hasil tangkapan ketiga tipe MPS diperlihatkan pada Gambar 2.

Dominasi kembung terlihat nyata dalam hasil tangkapan MPS Indramayu pada bulan Februari (musim barat), yaitu sekitar 34\% (Gambar 2A), sedangkan ikan bentong pada bulan Juni (musim timur) (28\%). Perbedaan ini diperkirakan berhubungan dengan habitat spesifik kedua spesies tersebut. Pada musim barat terjadi pengenceran oleh air tawar (sungai dan hujan) sehingga salinitas perairan pantai menurun, ikan kembung bermigrasi lebih ke tengah dan tertangkap armada ini, sedangkan pada musim timur keadaan perairan lebih asin yang memberi peluang bagi ikan bentong ke zona perairan ini. Habitat spesifik ikan kembung di perairan dengan salinitas lebih rendah nampak jelas dalam hasil tangkapan MPS Brebes yang beroperasi
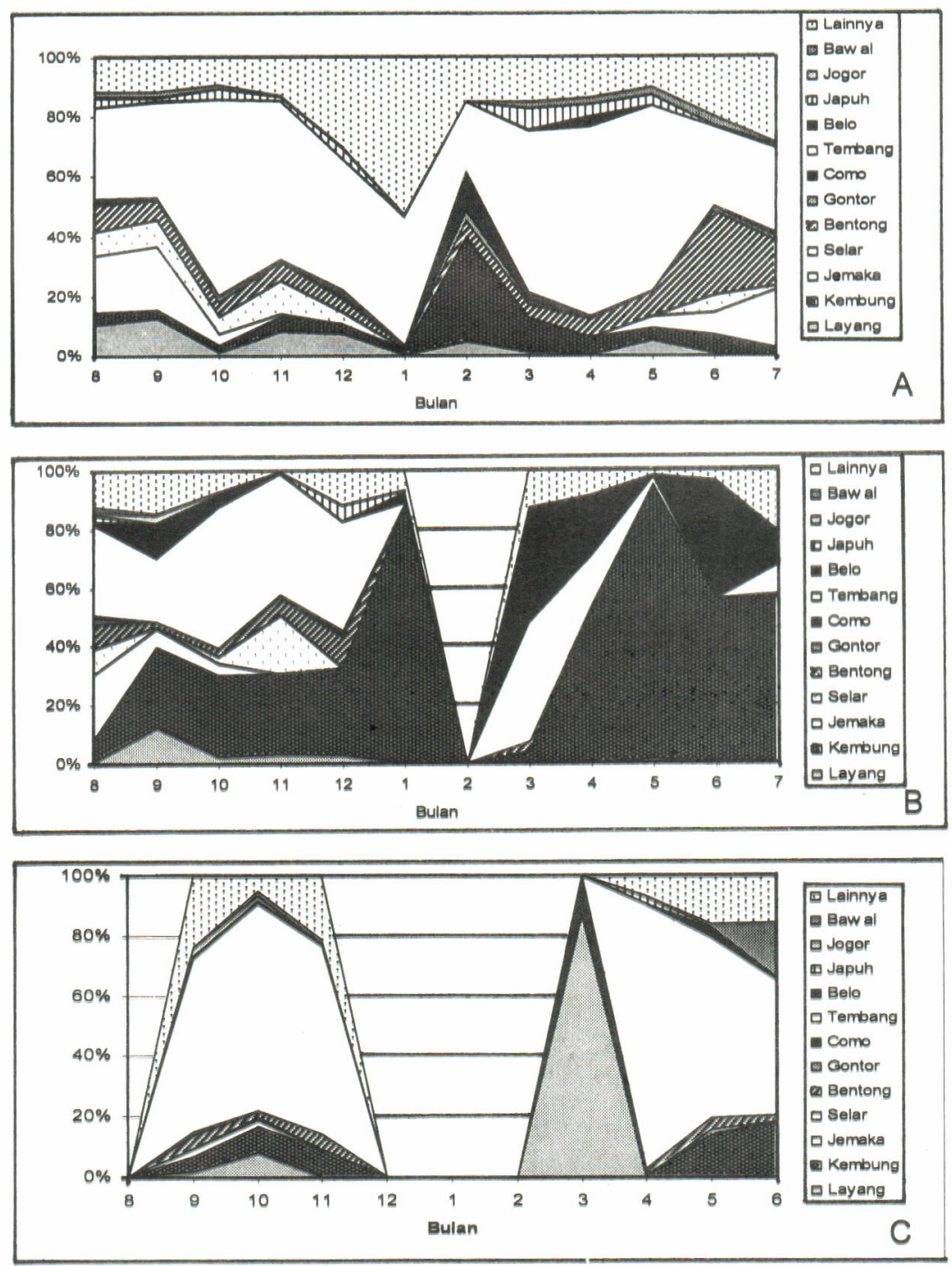

Gambar 2. Perbandingan komposisi jenis hasil tangkapan ikan pelagis kecil yang tertangkap oleh tiga jenis mini purse seine (MPS) di Indramayu (A), Brebes (B), dan Jawa Timur (C).

Figure 2. The comparison of small pelagic spesies composition, landed by the three types of mini purse seine: Indramayu (A), Brebes (B), and East Java (C). 
lek)h ke pinggir dengan cara memburu ('borahan'). Dominasi paling tinggi dari ikan kembung pada tipe MPS ini terjadi antara bulan Januari (87\%) dan Mei $(93 \%)$. Oleh MPS Brebes, bentong tertangkap lebih sedikit. Ikan belo memiliki sifat seperti kembung, yaitu lebih dominan dalam perairan yang lebih pinggir Karakteristik jenis-jenis di atas lebih diperjelas lagi dalam hasil tangkapan MPS Jawa Timur; selain itu, juga tertangkap ikan layang (Decapterus. spp.) yang dominan pada bulan Maret. Dominasi layang pada MPS Indramayu berpola sama dengan hasil tangkapan purse seine di Laut Jawa pada umumnya.

Dari hal tersebut di atas terlihat bahwa perubahan komposisi jenis dalam hasil tangkapan yang menggambarkan perubahan kelimpahan diduga berhubungan dengan perbedaan toleransi terhadap perubahan lingkungan (salinitas). Hasil yang sama juga dikemukakan oleh Atmaja \& Nugroho (1999) dalam studinya pada MPS Rembang dan MPS Jawa Timur yang mendarat di Pekalongan. Perubahan komposisi jenis dalam hasil tangkapan MPS ternyata lebih mencerminkan perubahan kondisi lingkungan daripada perbedaan dalam taktik penangkapan. Selain itu, nampak gejala saling menggantikan antara dua spesies menurut musim di antara spesies-spesies dominan, misalnya antara kembung, bentong, dan tembang. Di perairan utara Pekalongan jenis tembang/juwi dan kembung dominan (eksploitasi oleh MPS Jawa Timur); di Utara Rembang ikan layang, banyar, dan tembang juga dominan dan mirip dengan hasil tangkapan purse seine Laut Jawa karena kondisi salinitas lebih tinggi (Atmaja, 1995). Sebagai bagian dari Laut Jawa, selain variabilitas musiman (angin munson) perubahan salinitas di pantai utara Jawa juga dipengaruhi oleh massa air tawar dari sejumlah aliran sungai (Soeriaatmadja, 1956).

\section{Reproduksi dan Lingkungan Perairan}

\section{Kematangan gonad}

Dari pengamatan terhadap kematangan ikan contoh selama bulan Mei-Desember 2002, sebagian besar ikan contoh masih dalam kondisi pematangan
(TKG III, maturing). Perkembangan ke arah kematangan yang ditunjukkan oleh perkembangan ukuran gonad dan telur nampak jelas pada ikan kembung di Teluk Jakarta yang pada bulan Desember (musim barat) memiliki Gl paling tinggi (antara 0,41,05 , rata-rata 0,8 ) dengan jumlah ikan yang lebih matang (TKG III) paling besar (67\%) (Gambar 3). Sedangkan populasi ikan kembung di perairan Indramayu pada bulan Agustus dan Oktober umumnya lebih banyak didominasi oleh ikan-ikan muda yang belum matang (Tingkat I dan II).

Pada Gambar 4 ditunjukkan kondisi kematangan gonad spesies lain yang diperoleh di Teluk Jakarta; sedangkan keragaman nilai GI-nya disajikan pada Tabel 1. Spesimen dalam kondisi matang (early ripe) dijumpai pada ikan belo yang diamati pada bulan September, jumlahnya sekitar $25 \%$ dengan GI maksimum sebesar 3,5 (berat ovari segar 11,8 gram), yaitu pada kelas ukuran panjang $15 \mathrm{~cm}$ FL (berat ratarata 79 gram). Hal yang sama terjadi pada ikan bentong pada bulan Desember, jumlahnya $23 \%$. Spesimen ovari dalam kondisi matang ditandai oleh penampakannya, warna pink jernih, memenuhi rongga badan, seperti agar, telur besar dan transparan.

Meskipun harus didukung oleh data yang lebih lengkap, dari uraian di atas terlihat bahwa perkembangan ke arah kematangan sebagai indikasi pemijahan pada sekitar musim barat (setelah Desember) dari jenis-jenis ini mungkin terjadi di Kepulauan Seribu. Di Laut Jawa bagian tengah, tanpa menyebut lokasi spesifik sebagai daerah pemijahan dikemukakan bahwa puncak musim pemijahan lima spesies ikan pelagis kecil (layang, deles, banyar, siro, dan bentong) yang tertangkap purse seine diduga berlangsung sekitar musim barat (Atmaja et al., 1995).

Di Selat Sunda, pengambilan contoh pada musim timur (Juli-Agustus) menunjukkan adanya indikasi pemijahan dari layang deles. Dari ikan contoh sebanyak 170 ekor, 63 ekor di antaranya betina (sex ratio $=1: 1,7)$; dari contoh ikan betina tersebut $60 \%$ di

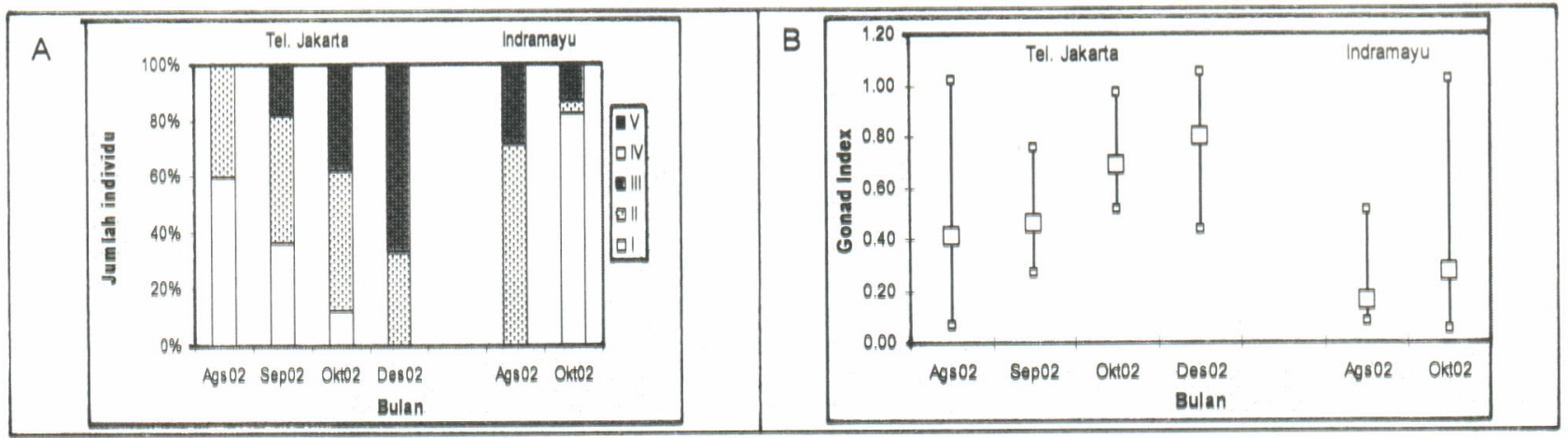

Gambar 3. Perkembangan kematangan gonad ikan kembung di Teluk Jakarta dan perairan utara Indramayu (A. Tingkat Kematangan; B. Gonad Index).

Figure 3. The development of sexual maturity of short bodied mackerel in Jakarta Bay and northern Indramayu ( $A$. maturing, $B$ gonad index). 


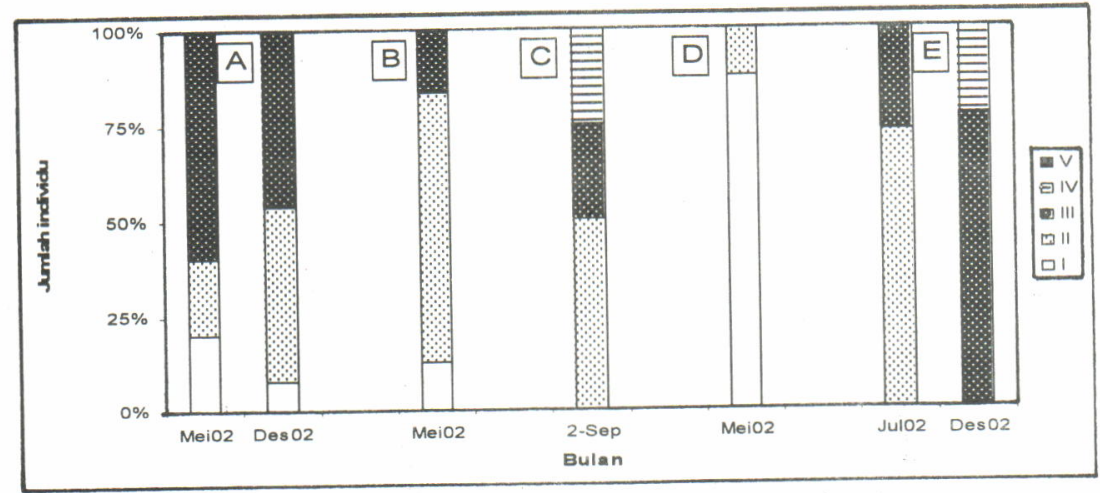

Gambar 4. Kondisi kematangan (TKG) beberapa spesies ikan pelagis lainnya di Teluk Jakarta: A. Rastrelliger kanagurta; B. Selar boops; C. Sardinella brachysoma; D. Decapterus macrosoma; E. Selar crumenophthalmus).

Figure 4. Maturity condition (M) of the others several pelagic species in Jakarta Bay: A. Rastrelliger kanagurta; $B$. Selar boops; C. Sardinella brachysoma; D. Decapterus macrosoma; E. Selar crumenophthalmus).

Tabel 1. Keragaman nilai GI dari beberapa spesies ikan pelagis di daerah penelitian

Table 1. The diversity of GI (Gonad Index) values of several small pelagic species in the survey area

\begin{tabular}{lllllc}
\multicolumn{1}{c}{\begin{tabular}{c} 
Spesies \\
\multicolumn{1}{c}{ Species }
\end{tabular}} & \multicolumn{1}{c}{ Lokasi } & \multicolumn{1}{c}{$\begin{array}{c}\text { Bulan } \\
\text { Location }\end{array}$} & Month(2002) & Min & Gonad Index \\
Max & Mean \\
\hline R. kanagurta & Teluk Jakarta & Mei & 0,03 & 0,93 & 0,49 \\
& & Desember & 0,05 & 0,60 & 0,27 \\
S. brachysoma & Teluk Jakarta & September & 0,37 & 3,48 & 1,31 \\
S. boops & Teluk Jakarta & Mei & 0,08 & 0,62 & 0,31 \\
D. macrosoma & Teluk Jakarta & Mei & 0,06 & 0,45 & 0,12 \\
& Selat Sunda & Juli & 0,14 & 0,83 & 0,35 \\
S. crumenophthalmus & & Agustus & 0,76 & 1,24 & 0,96 \\
& Teluk Jakarta & Juli & 0,17 & 0,53 & 0,31 \\
& & Desember & 0,35 & 0,94 & 0,60 \\
\hline
\end{tabular}

antaranya masih dalam tahap pematangan (TKG III) sedangkan $31 \%$ lainnya sudah matang (early mature dan mature).

\section{Sampling larva}

Dari sampling larva tampak selalu diperoleh contoh larva/telur dengan kelimpahan bervariasl. Kelimpahan yang lebih tinggi diperoleh di perairan utara Indramayu pada bulan Desember (Gambar 5), yaitu sekitar 5.140 individu (telur/larva) per liter air laut, sedangkan pada bulan Juni jauh lebih sedikit (150 individu per liter). Di Selat Sunda, sampling pada musim barat memperlihatkan kelimpahan yang rendah dari larva/telur ikan, yaitu hanya sekitar 100 individu/liter, sedangkan pada musim timur kelimpahannya lebih tinggi, yaitu 3.100 individu/liter. Belum diketahul secara pasti spesies ikan yang menghasilkan telur/larva tersebut, namun data ini mendukung dugaan pemijahan seperti diuraikan di atas.

Di samping telur/larva Ikan, beberapa Jenis zooplankton lain juga ikut terjaring seperti telur/larva udang, sagitta (cacing) dan plankton lain seperti ditunjukkan pada Gambar 5. Kopepoda umumnya lebih dominan di kedua perairan. Dari hasil pengukuran parameter fisik perairan, terdapat perbedaan suhu yang cukup tajam antara bulan Juni dan Desember di perairan utara Indramayu; pada bulan Desember suhu perairan lebih tinggi (rata-rata $31,1^{\circ} \mathrm{C}$ ) dibandingkan bulan Juni (rata-rata $28,7^{\circ} \mathrm{C}$ ) (Tabel 2). Perbedaan ini diduga menjadi faktor yang mendukung pemijahan. Perbedaan juga terlihat pada sallnitas: salinitas rata-rata pada bulan Desember sebesar $33,2 \%$ sedangkan pada bulan Juni sebesar $31,1 \%$. Perbedaan salinitas pada dua musim in nampak bertentangan mengingat kondisi musim. Namun hal inl diduga disebabkan oleh pemolaan massa air yang menciptakan kondisi khusus di zona perairan ini. Pada musim hujan, di pantal utara Jawa baglan barat (utara Indramayu) terdapat massa air dengan salinitas $>33 \%$ (Durand \& Petit, 1995). Pengukuran suhu dan salinitas pada kedua musim dl Selat Sunda memperlihatkan kondisi yang hampir sama (Tabel 2). 


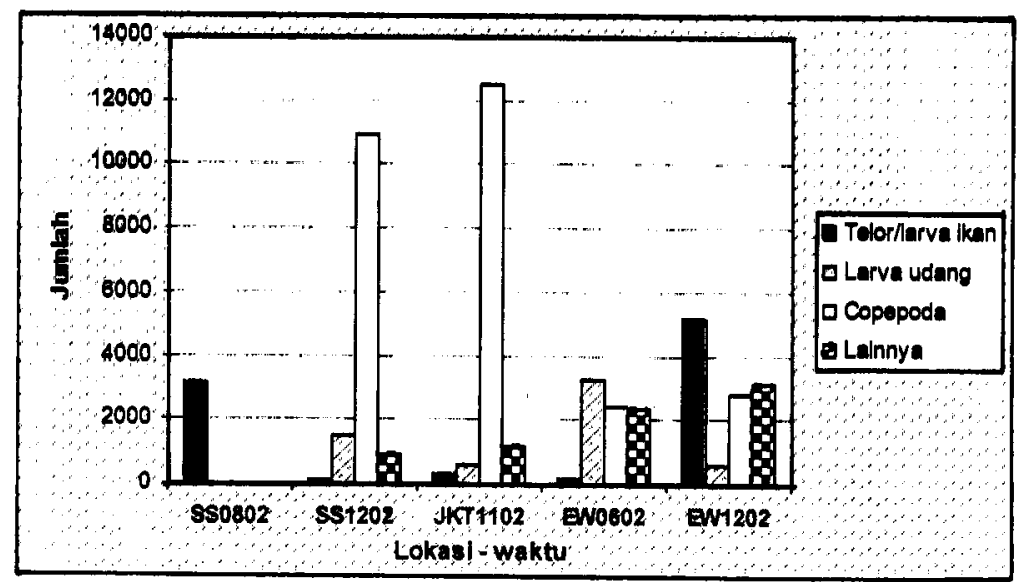

Gambar 5. Variasi musiman kelimpahan zooplankton (individu/liter) di perairan Selat Sunda (SS), Teluk Jakarta (JKT), dan utara Indramayu (EW) tahun 2002.

Figure 5. Seasonal variation of zooplankton abundance (individu/liter) of Sunda Strait (SS), Jakarta Bay (JKT), and northern Indramayu (EW) in 2002.

Tabel 2. Kecerahan, suhu, dan salinitas di perairan utara Indramayu dan Selat Sunda

Table 2. Transparency, temperature, and salinity recorded in the waters of Sunda Straits and northern Indramayu

\begin{tabular}{clcccc}
\hline $\begin{array}{c}\text { Lokasi } \\
\text { Location }\end{array}$ & \multicolumn{1}{c}{$\begin{array}{c}\text { Bulan } \\
\text { Month }\end{array}$} & $\begin{array}{c}\text { Depth } \\
(\mathbf{m})\end{array}$ & $\begin{array}{c}\text { Kecerahan } \\
\text { Turbidity }(\mathrm{m})\end{array}$ & $\begin{array}{c}\text { Temperature } \\
\left({ }^{\circ} \mathbf{C}\right)\end{array}$ & $\begin{array}{c}\mathbf{S} \\
(\%)\end{array}$ \\
\hline Indramayu & Juni & 12 & 4,5 & 28,7 & 31,1 \\
& Desember & 14 & 4,8 & 31,1 & 33,2 \\
Selat Sunda & Agustus & 50 & 8,6 & 29,4 & 32,5 \\
& Desember & 48 & 9,0 & 29,5 & 32,6 \\
\hline
\end{tabular}

\section{Kebiasaan makan dan kelimpahan plankton}

Ikan kembung merupakan ikan pemakan plankton. Dari 20 ikan contoh yang diamati per lokasi sampling plankton diatom umumnya merupakan diet utamanya, plankton lainnya adalah dinoflagellata, tintinid, kopepoda, dan lainnya. Dominasi diatom dalam makanan menunjukkan variasi secara bulanan dan lokasi perairan (Gambar 6). Pada musim timur di perairan utara Indramayu jenis ikan ini di duga makan diatom paling banyak. Berdasarkan ikan contoh yang diamati menunjukkan bahwa dominasi diatom dalam makanan ini lebih rendah untuk ikan contoh yang berasal dari Teluk Jakarta.

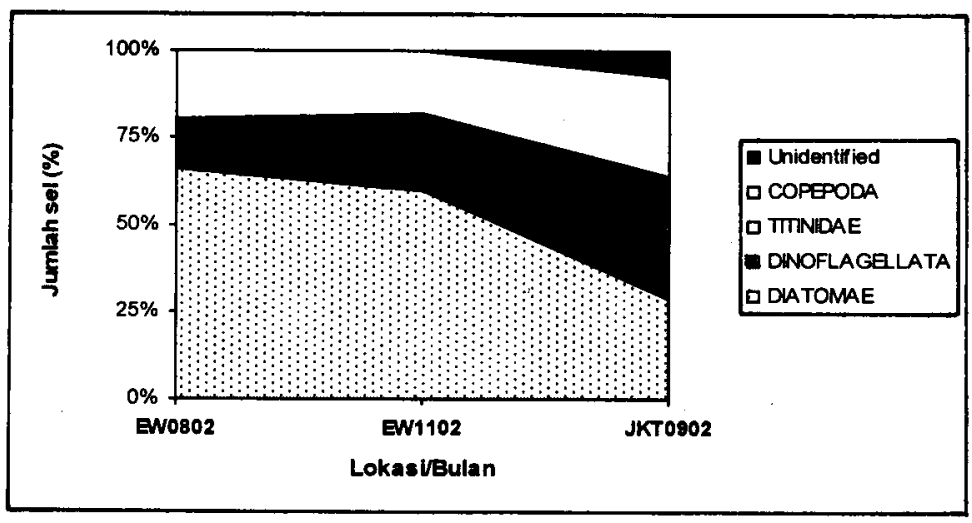

Gambar 6. Variasi komposisi makanan ikan kembung menurut waktu dan lokasi (EW: Utara Indramayu; JKT: Teluk Jakarta).

Figure 6. Variation of food composition of short bodied mackerel by time and location (EW: Northern Indramayu, JKT: Jakarta Bay) 
Terdapat hubungan yang nyata antara komposisi diet dengan kelimpahan plankton dalam perairan. Dari pengambilan contoh plankton, diatom umumnya merupakan komponen penting di seluruh perairan selain cyanophyta, dinoflagellata, dan kopepoda seperti ditunjukkan pada Gambar 7, sedangkan fluktuasi kelimpahan seluruh plankton menurut musim dan lokasi dipresentasikan pada Gambar 8. Diatom umumnya lebih dominan pada musim timur, sedangkan Cyanophyta dominan pada musim barat. Di perairan utara Indramayu pada musim timur hampir $95 \%$ dari seluruh plankton terdiri dari diatom, sedangkan pada musim barat hanya sekitar $35 \%$. Plankton lain yang juga dominan pada musim barat (di utara Indramayu dan Selat Sunda) adalah Cyanophyta.

Diatom juga ditemukan paling melimpah di Teluk Jakarta pada bulan Nopember (musim peralihan).
Variasi dalam dominasi plankton menurut musim diperkirakan berhubungan dengan kondisi lingkungan perairan.

Secara umum kelimpahan plankton di perairan utara Indramayu lebih tinggi dibandingkan dengan perairan lainnya (Teluk Jakarta dan Selat Sunda). Pada musim timur total kelimpahannya lebih tinggi yakni mencapai 1.900 ribu sel/liter, sedangkan pada musim barat 950 ribu sel/liter (Gambar 7). Di Teluk Jakarta pada bulan Mei (musim timur) kelimpahan diatom paling tinggi sekitar $214 \mathrm{ribu} \mathrm{sel} / \mathrm{m}^{3}$ atau 0,92 $\mathrm{ml} / \mathrm{m}^{3}$ (Nontji \& Arinardi, 1975). Hasil penelitian Nontji (1977) menyebutkan bahwa konsentrasi klorofil-a di Laut Jawa pada musim timur (September-Oktober) lebih tinggi dibanding musim barat (Maret-April), nilai rata-ratanya masing-masing adalah $0,19 \mathrm{mg} / \mathrm{m}^{3}$ dan $0,18 \mathrm{mg} / \mathrm{m}^{3}$.

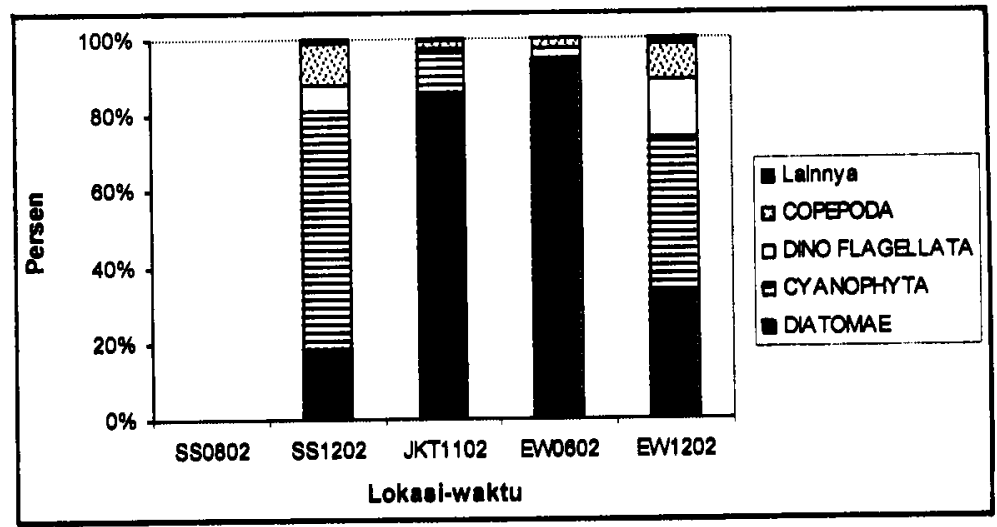

Gambar 7. Komposisi plankton menurut musim dan lokasi tahun 2002 (SS: Sel. Sunda; JKT: Teluk Jakarta; EW: Utara Indramayu).

Figure 7. Composition of plankton by season and location in 2002 (SS: Sunda Strait, JKT: Jakarta Bay, EW: Northern Indramayu).

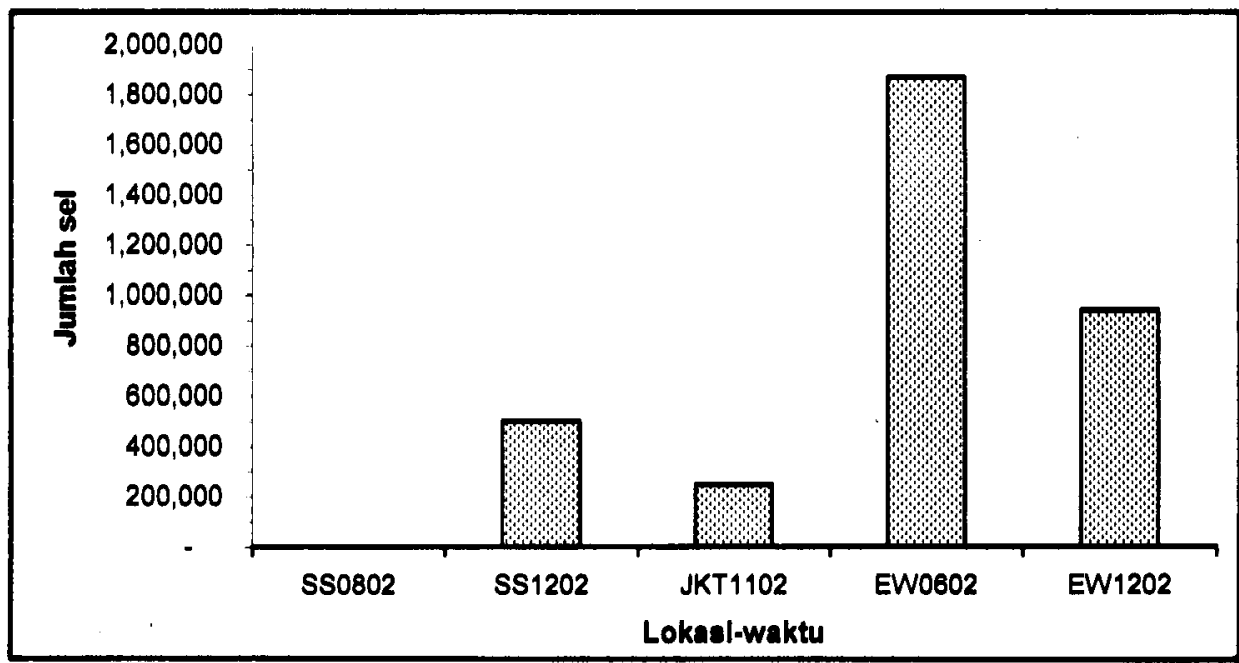

Gambar 8. Total kelimpahan fitoplankton menurut musim dan lokasi tahun 2002 (SS: Sel. Sunda; JKT: Teluk Jakarta; EW: Utara Indramayu).

Figure 8. Total abundance of phytoplankton by season and location in 2002 (SS: Sunda Stralt, JKT: Jakarta Bay, EW: Northern Indramayu). 


\section{KESIMPULAN DAN SARAN}

Dari uraian tersebut di atas dapat disimpulkan:

1. Terdapat perubahan jenis ikan pelagis dalam hasil tangkapan yang ditentukan oleh perubahan musim. Kemunculan jenis dominan terutama dipengaruhi oleh toleransinya pada kondisi lingkungan (salinitas). Kecenderungan saling menggantikan antara dua atau lebih spesies diduga juga mengikuti perubahan lingkungan (musim).

2. Sebagian besar populasi ikan pelagis kecil terdiri dari ikan-ikan yang belum matang gonad, indikasi pemijahan terjadi pada musim barat di perairan Teluk Jakarta dan setelah musim timur di Selat Sunda.

3. Variasi dalam diet ikan diduga seirama dengan komposisi plankton dalam perairan.

4. Perubahan kondisi lingkungan antara musim timur dan musim barat juga menciptakan perbedaan dalam komposisi dan kelimpahan plankton dan larva ikan.

5. Fluktuasi kelimpahan larva/telur serta plankton diperkirakan mengikuti perubahan musim dan pola-pola massa air belum diketahui.

\section{DAFTAR PUSTAKA}

Atmaja, S.B., 1995. Identifikasi aktivitas penangkapan dan target spesies pukat cincin mini di pantai utara Jawa. Prosiding Seminar Kelautan Nasional, Jakarta 15-16 Nopember 1995. Panitia
Pengembangan Riset dan Teknologi Kelautan serta Industri Maritim, p: II--23.

Atmaja, S.B. \& D. Nugroho, 1999. Perikanan pukat cincin mini di pantai utara Jawa: daerah operasi, aktivitas penangkapan dan hasil tangkapan. Jurnal Penelitian Perikanan Indonesia, V(4): 43--50.

Durand, J.R. 7 \& D. Petit, 1995. The Java Sea environment. In: Potier, M. \& S. Nurhakim (eds.), BIODYNEX: Biology, Dynamics, Exploitation of the Small Pelagic Fishes in the Java Sea. AARD/ORSTOM, p: 15--38.

Hariati, T., M.M. Wahyono, Suwarso \& D. Krissunari, 1995. North coast fisheries: preliminary observations on small seine nets exploitation. In: Potier, M. \& S. Nurhakim (eds.), BIODYNEX: Biology, Dynamics, Exploitation of the Small Pelagic Fishes in the Java Sea. AARD/ORSTOM, p: $185-194$.

Nontji, A., 1977. Notes on the chlorophyll distribution around Jawa. Oseanologi di Indonesia, VII: 43--47.

Nontji, A. \& O.H. Arinardi, 1975. Hidrologi dan diatom plankton di Laut Jawa. Oseanologi di Indonesia, IV: $21--36$.

Soeriaatmadja, Rd. E., 1956. Seasonal Fluctuation in the Surface Salinity off the North Coast of Java. Marine Research in Indonesia, I: 1--19.

Yamaji, 1996. Illustration of the marine plankton of Japan. Hoikusha Publishing Co. Ltd. Japan, 538 pp. 